\title{
Inquiry-based Learning in Higher Education: A Pedagogy of Trust
}

\author{
Beth Archer-Kuhn ${ }^{1}$, Stacey MacKinnon ${ }^{2}$ \\ ${ }^{1} \mathrm{PhD}$, Faculty of Social Work, University of Calgary, Calgary, AB, Canada \\ ${ }^{2} \mathrm{PhD}$, Department of Psychology, University of Prince Edward Island, Charlottetown, PEI, Canada \\ Correspondence: Beth Archer-Kuhn, PhD, Faculty of Social Work, University of Calgary, Calgary, AB, Canada.
}

Received: July 13, $2020 \quad$ Accepted: July 28, $2020 \quad$ Online Published: July 29, 2020

doi:10.11114/jets.v8i9.4929 URL: https://doi.org/10.11114/jets.v8i9.4929

\begin{abstract}
This qualitative constructivist grounded theory study of trust within inquiry-based learning in higher education (IBL-HE) environments examined the experiences of instructors and students through four focus groups and nine individual interviews. As the study purpose is to understand the development and maintenance of trust in IBL-HE classrooms, participants are experienced instructors, learners, and authors of IBL-HE from Canada, USA, New Zealand, and Ireland. We used face-to-face sessions and zoom sessions to facilitate the focus group experience, and telephone for the individual interviews to explore the following two research questions: (1) what does trust mean in a higher education IBL (IBL-HE) classroom; and, (2) how do those involved create and maintain it? Our findings are revealed through our Pedagogy of Trust in IBL-HE using 3 themes: (1) Creating an environment of negotiated mutuality; (2) Emerging relationship/community building; and, (3) Internalizing and applying a mindset shift. Each of these stages involved a different trust relationship: (1) Professor-Student; (2) Student-Student; and, (3) Student-Self. These findings provide evidence for IBL as a pedagogy of trust in higher education, and reinforce the need for the Scholarship of Teaching and Learning (SoTL), and the lifelong learning skills desired by contemporary employers.
\end{abstract}

Keywords: inquiry-based learning, trust, higher education, pedagogy, constructivist grounded theory

\section{Introduction}

Human development is predicated on the practice of inquiry, specifically the process of observing and questioning within our environment (Gopnik, Meltzoff, \& Kuhl, 1999). Inquiry-based learning (IBL) is very effective in enhancing students' ability to inquire, proficiently research, and solve problems, the top three characteristics that employers seek (Coplin, 2012; Rancourt \& Archer-Kuhn, 2019). IBL can help students critically evaluate the information they receive (Braye, Lebacq, Mann, \& Midwinter, 2003; Cook \& Borkovitz, 2017; Hairida, 2016), enhance content retention (Richmond et al., 2015), increase motivation to learn (Archer-Kuhn, Lee, Finnessey \& Liu, 2020; Wang, Wu, Yu \& Lin, 2015; Zafra-Gomez, Roman-Martinez \& Gomez-Miranda, 2015;), and improve overall learning \& self-confidence (von Renesse \& Ecke, 2017; Wall, Dillon \& Knowles, 2015). As an added bonus, IBL is generally enjoyed by students (Archer-Kuhn, Chalifoux, \& Wiedeman (in press); Ural, 2016), leading to greater student engagement in their learning (Archer-Kuhn, Lee et al., 2020; Smallhorn, Young, Hunter, \& de Silva, 2015). Experienced IBL learners may be better prepared to succeed in the workforce as the process supports the development of additional lifelong learning skills, such as ongoing reflection, curiosity, critical thinking, and collaborative work with diverse teams and clientele (Almajed, Skinner, Peterson, \& Winning, 2016; Anstey, 2017; Braye et al., 2003; Crick, 2009; Dyche \& Epstein, 2011; Inglis, Statham, \& Hanekam, 2014). All of these benefits have been found to lead to an increase in satisfaction in post-graduation employment (Summerlee, 2018).

With many universities and colleges (e.g., McMaster, University of Calgary, SUNY, Elon, UTexas, Portland State, Boston University) advocating for more of this kind of high-impact experiential, inquiry-based pedagogy in the classroom, we need to determine how best to implement and sustain successful IBL practices in higher education; an environment which differs significantly from the K-12 classrooms in which most IBL research has been conducted (Friesen \& Scott, 2013). This study focuses on one of those key environmental factors, specifically trust.

\subsection{Why Does Trust Matter in IBL?}

Inquiry-based Learning (IBL) is a self-directed, question-driven approach to understanding that gives students the opportunity to explore a subject in-depth and develop central questions throughout their exploration (Hudspith \& Jenkins, 
2007; Hudspith, Jenkins \& Hills, 2003). As students are encouraged to engage with various resources, support and collaborate with their peers, and work through the struggles of conducting research to answer their inquiry question (Anstey et al., 2014), this approach requires instructors to become facilitators who support and guide students on their learning journey (Sproken-Smith \& Walker, 2010) which allows students to become more responsible for and take ownership of their own learning (Love, Hodge, Corritore, \& Ernst, 2015; Yang, 2015). Students and instructors can struggle with this change in dynamic as it is challenging, and goes against the norms wherein the teacher is an authority figure and gatekeeper of new information. Success in higher education IBL experiences therefore requires a significant shift in perspective amongst these stakeholders (Brubaker, 2012; Bolhuis, 2003; Cuneo, Harnish, Roy, \& Vajoczki, 2012).

These perspective shifts can result in the uncomfortable juxtaposition of enjoying being challenged while simultaneously questioning one's personal competency and inciting fear of failure often due to delaying numerical assessment in favor of receiving regular formative feedback (Litmanen, Lonka, Inkenen, Lipponen \& Hakkarainen, 2012). In addition, IBL classrooms focus on the process of learning as much or more than the final product, leaving little room for procrastination or avoidance. IBL can provoke anxiety for both students and instructors who must learn to "get comfortable with being uncomfortable" given the likelihood of making mistakes, taking wrong turns and encountering "speedbumps" along the IBL journey (Boyle \& MacKinnon, 2016; Brubaker, 2012; von Renesse \& Ecke, 2012).

Whereas trust is widely accepted to be a key component of the learning process in general (Henschke, 2013; MacFarlane, 2009), the unique constellation of circumstances presented by the university experience make the quick and meaningful development of trust a necessary condition for taking intellectual risks. These unique circumstances include: short semesters (four months to one week), larger classes (30-100+ students), high stakes and outcome focus in which students and instructors feel the pressure for goal achievement in the service of career development (Boyle \& MacKinnon, 2016; Shin \& Jung, 2014), as well as unrealistic expectations and negative stereotypes of what learning in higher education will/should be (e.g., Bunce, Baird, \& Jones, 2017; MacKinnon, 2017).

To further complicate matters, scholars have identified a variety of trusting relationships as necessary antecedents to successfully facilitate IBL in higher education (hereafter referred to as "IBL-HE") including mutual trust between the students (particularly when group work is involved), students and/instructors, instructors and administration, and trust in the pedagogy itself are important (Boyle \& MacKinnon, 2016; Cook \& Borkovitz, 2017; Cooper, Bailey, Briggs, \& Holliday, 2017; Cuneo et al., 2012; Harvie, Harper-Tavers \& Jaeger, 2017; Justice et al, 2009; Love et al., 2015; MacKinnon, 2017; Yang, 2015). Research on how to develop and maintain these types of trust in higher education settings, particularly when instructors and students are attempting to step outside their comfort zones and engage in IBL however, is sparse (Aditomo, Goodyear, Bliuc, \& Ellis, 2013; Beltrano, Archer-Kuhn, \& MacKinnon (under review); Friesen \& Scott, 2013; Risley \& Petroff, 2014). In-depth qualitative research examining the lived experience of trusting in IBL-HE environments is virtually non-existent (see Boyle \& MacKinnon, 2016 for an exception).

In 2018, we brought together a group of scholars, faculty members (aka instructors) and university students from Canada, the US and the UK to examine in detail the ways in which we were working to reignite a sense of curiosity and the skills of inquiry in our higher education students. This working conference highlighted both the successes and challenges of creating an inquiry-oriented, student-owned undergraduate learning experience. From this in-depth discussion between national and international teaching award winners, those newly embarking on academic careers, and students who had experienced inquiry-based courses, we determined that one area of perplexity we all shared was embedded in the concept of developing and maintaining the various forms of trust.

The purpose of this research study is to uncover the meaning, development and maintenance of trust in IBL-HE from the perspectives of students and faculty members. We utilized constructivist grounded theory (Charmaz, 2006) to analyze the experiences and reflections of a series of scaffolded focus groups and individual interviews with faculty members and students who have engaged in IBL in higher education. Our study began with our two-day intensive working conference where we explored two key research questions that needed to be addressed regarding IBL in higher education: What does trust mean in a higher education IBL (IBL-HE) classroom and how do those involved create and maintain it? This study received ethics approval from the universities of Calgary and Prince Edward Island. All faculty and student participants, including those from the original working conference provided informed consent.

\section{Methods}

Using a qualitative research design (Creswell, 2013) and constructivist grounded theory methodology (Charmaz, 2006), we facilitated four focus groups $(\mathrm{N}=20)$ and conducted in-depth one on one interviews $(\mathrm{N}=9)$ with both instructors and students (see Appendix A Table 1) who were experienced in inquiry-based learning in higher education (Marshall \& Rossman, 2016). This data collection was conducted in a series of three scaffolded steps using purposive and snowball sampling (Creswell, 2013). All focus group discussions were facilitated by one researcher while the other took detailed field notes. As each was completed, the focus group discussions and interviews were transcribed verbatim and we 
conducted a stepwise constructivist grounded theory analysis (Charmaz, 2014).

Step one focused on the experiences of instructors engaged in inquiry-based learning in higher education. We first conducted an in-person focus group with six faculty members who had attended our working conference. Detailed analysis of this data informed the content of our second instructor focus group which was conducted using group video chat (Zoom) and included four participants who varied from a pre-tenure professor to one with 40 years of inquiry-based learning experience.

Step two focused on students who had experienced inquiry-based learning at least once in higher education. Our goal with the student focus groups was two-fold: first, to solicit the student perspective on building and maintaining trust in intellectual risk-taking classrooms such as IBL, and second, to ask student to reflect on our findings from the instructors focus groups to determine the extent to which what instructors believe successfully builds trust is truly working and what, if any assumptions instructors are making that are not valid or more nuanced from the student perspective. Both student focus groups were conducted using group video chat (Zoom) by our trained senior undergraduate student research assistants to ensure optimal student comfort in discussing the impact of instructors' actions on their trust and willingness to take intellectual risks in IBL classrooms.

Step three involved in-depth one on one interviews with additional instructors and students and focused on further detailed development of the theories of trust emerging from the scaffolded focus groups.

\subsection{Stepwise Constructivist Grounded Theory Analysis}

Constructivist grounded theory (Strauss \& Corbin, 1990) acknowledges that theories and data are co-constructed by study participants and researchers. Systematic analysis of the data in this study therefore consisted of initial, focused and theoretical coding as each step of data collection was completed (Charmaz, 2014). Initial coding involved considering the data line by line and assessing what was happening and what theoretical ideas it suggested and also constant comparative methods within and across focus groups and interviews. Two research assistants conducted independent interrater reliability analyses (McAlister et al, 2017; Armstrong, Gosling, Weinman, \& Marteau, 1997) using constant comparison methods within and across focus groups. No disagreements were identified between the two research assistants or between the research assistants and the initial coding by the primary investigators.

Focused coding then concentrated on clarifying and developing the most frequent and significant initial codes and constructed categories. As a result, at each step of the data collection process, patterns emerged around salient topics, or "sensitizing concepts" (Blumer 1969), such as time and power. We remained cognizant of these concepts as we collected more data, further probing the instructors and students to flesh out our understanding of the complexity of their experience.

We then engaged in theoretical coding, formulating tentative theories to explain the patterns that emerged from our focused coding with some additional focus groups/interviews supporting our developing analysis and some refuting it, but all progressively helping us develop and hone our conceptual framework (Charmaz, 2014). We ended data collection when we believed we had reached theoretical saturation or the point at which gathering more data about a theoretical category no longer yields are further insights into the emerging grounded theory.

\section{Findings}

Instructors and students in our study unanimously agreed that trust is an essential component of success in IBL-HE. Based on these focus groups and interviews, we determined that their IBL-HE experiences with trust involved three distinct themes: (1) Creating an environment of negotiated mutuality; (2) Emerging relationship/community building; and, (3) Internalizing and applying a mindset shift. Each of these themes involved a different trust relationship: (1) ProfessorStudent; (2) Student-Student; and, (3) Student-Self. 


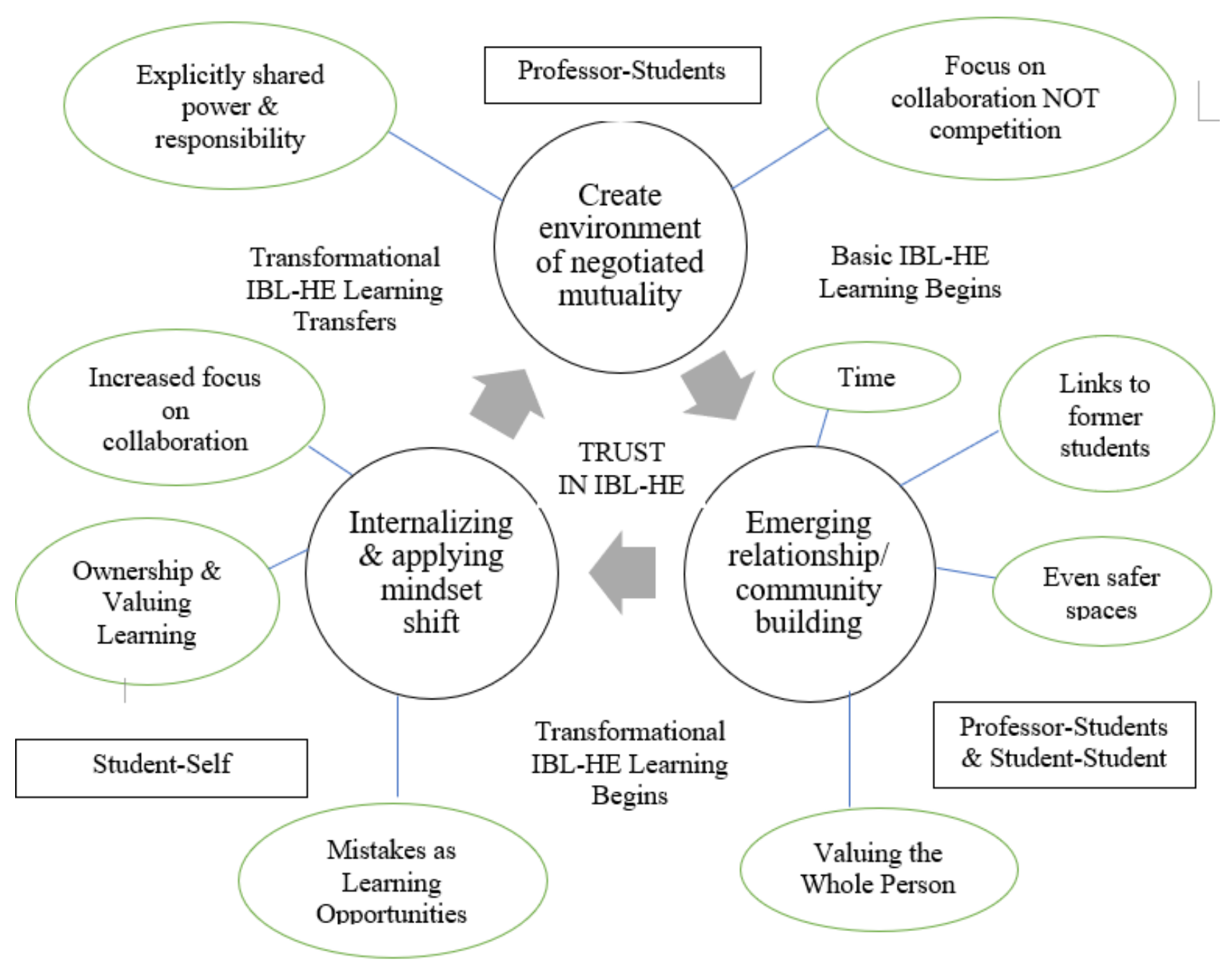

Figure 1. Pedagogy of Trust in IBL-HE

\subsection{Creating an Environment of Negotiated Mutuality}

According to our participants, trust and basic IBL-HE learning begins when the professor sets the stage by creating an environment of "negotiated mutuality" and models the willingness to engage in intellectual risk-taking as a desirable mindset. One faculty member discussed this intellectual risk-taking as involving being "vulnerable to one another in the process of learning with favourable expectations but no certainty of positive results." For instructors, the vulnerability of IBL-HE comes from the lack of certainty concerning student buy-in. Unlike lectures or other professor-driven approaches, if even a small group of the students do not fully engage in IBL the learning experience can end up being negative for all. As a result, the instructor is risking the learning of all students and indeed their own professional evaluations when engaging in IBL-HE. For students, the risks of IBL include not learning sufficiently, not getting the grades they need to move forward, and having to learn to act on formative feedback rather than relying on numerical assessments to guide their learning and often their feelings of self-esteem. For IBL-HE to succeed therefore, both instructors and students must accept the vulnerability that comes with intellectual risk taking and take a leap of faith that regardless of how many false starts or challenges they will face, their IBL-HE learning experience will ultimately be positive. One professor indicated that "credibility comes from who you are when you walk into the classroom, and what you say you are going to do but you really have to walk the talk." Faculty acting as a model of an active (and fallible) inquirer is key to IBL-HE success. Students are more willing to step up and take that leap of faith when the instructor shows their willingness to be a vulnerable learner too, a sentiment expressed by a student who suggested, "willingness on both the parts of the instructor and the student to step in to towards one another" matters.

According to our participants, for trust to begin it is incumbent on the instructor to "walk the talk" and demonstrate to students both in their own approach to learning and in the way they design the course that the IBL-HE classroom focuses on learning as a process, collaboration not competition, and that the power and responsibility for learning will be (and should be) explicitly shared between the instructor and their students. Beginning to develop mutual trust at this level is essential therefore because while students are expected to trust their professor, for IBL-HE to succeed instructors must 
also trust their students. As one student indicated:

I'm just thinking that it's such a learning curve right? ...they give the trust that like the professor is trusting you to do it and you're trusting the professor to trust you to trust that you'll do it too.

\subsubsection{Collaboration not competition Builds Mutual Trust}

To facilitate students' trust in themselves and the IBL-HE environment, instructors need to model their own trust in the IBL process itself and the students' ability to engage in the IBL process. One student noted, "I think it has a lot to do with who the professor is, how they are implementing the IBL course or how they're not really implementing it and how they are interacting with the students." Another student echoed the potential outcome of trusting a professor and a professor being trustworthy saying,

... trust is just kind of the rope you wrap yourself with as you jump into a deep dark hole...without that...students aren't able to go as deep in their own learning uh because they don't have people who are gonna' hold the rope for them when they jump in.

Knowing that the professor is "holding the rope" is key to students' willingness to engage in IBL-HE because IBL requires greater effort from students and an increased sense of responsibility for their learning. These increased expectations and responsibilities can leave students feeling exposed and afraid as their learning journey is on public display throughout the semester. As one professor observed:

As soon as I say, as kind of the last parting message, 'I will have your back no matter what happens.' I can almost see them relax, right? So, there is excitement, right? But I can see that there is tension, and when I say that, there is just 'OK, got you', response from the student.

\subsubsection{Shared but Not Equal Power \& Responsibility}

Despite the constructivist paradigm within which IBL is situated, both instructors and students noted power differentials within the IBL-HE classroom. Not surprisingly, instructors talked about the ways in which they attempt to share power in the IBL environment, while still acknowledging power as unequal. At the same time students were clear that although shared power is an important component in IBL, power remains (and they say, must remain) unequal in the student and instructor relationship. As this instructor makes clear, "as an educator, you may not put a lot of weight on the power that you are given in the classroom. Students perceive that power." One faculty member acknowledged the intentionality around power that is required by instructors in an IBL course, indicating "The onus is on the instructors, to really break down those power relationships and that they really do mean this is a collegial setting. Everyone's ideas are equally valued." However, students understood power to be further complicated with the assignment of grades and the instructor having ultimate decision-making power about grade assignment suggesting that "the challenge to trust, uh, the instructor is definitely the power dynamics. It was difficult because they still held your grade at the end of day." Another student suggested that "... with grades being a currency in academia, like it, the professor is the banker and like the boss, and I think those power relations will always be there." Acknowledging the relational nature of instructor and student interactions within IBL courses, one student noted the ever presence of power, regardless of how they may experience IBL instructors who share power, who encourage shared power, and with whom they have shared a positive relationship:

The whole power dynamic, um, persists in the like discourse between, you know, a student and the professor.

And I think that even with IBL that, um, I think seeks to sort of dispel that gap between student and professor,

it's still here. It is. We've all had this beautiful experience of IBL and we're still talking about the power dynamic.

Instructors shared with us stories of some of the intentional choices they make in IBL courses to mitigate power imbalances and encourage collaboration in intellectual risk taking. For example, instructors said that they want students to see that they are not an expert of all things and at times they too can be wrong such as noted here, "...I let myself be vulnerable in that I am OK to be wrong...I am only one lens to see the world...I never present myself as an expert of anything. I am one funnel." Another faculty participant said the shift from traditional teaching to IBL occurs for students and faculty and requires some adjustment in the ways in which we think about teaching and learning, as we hear from this faculty member, "...there is a huge leap of faith for faculty to absolve themselves from being the fountain of knowledge and divesting that knowledge to the students." This shift in thinking about teaching and learning places everyone in the position of learner as one faculty member notes, "That we are all learners together and we are going to learn through this process." One key experience noted here by a student was an interaction with an IBL-HE instructor,

One of the things that I've really respected about her [the instructor] is that in terms of taking risks and sort of establishing a good environment in that way is just really being able to embrace her own failures or mishaps and just really being able to just be just so human in that way.

Trusting in intellectually risky situations can be trickier for students. One student participant describes relations of power as ever present which they say influences the degree of risk taking that student may choose to engage in, "The whole 
power dynamic, um, persists in the like discourse between, you know, a student and the professor." The student/professor relationship may begin in a traditional sense, however, participants say that within the IBL course this can shift. For example, student participants reflect on their engagement in learning as one of the ways in which mutuality is negotiated and power shifts from instructor to student through the transfer of knowledge as indicated here, "[the instructor] let us be experts where we can be experts." As the IBL course progresses, students experience the shift and an increase in their power as noted here, "so much of this project is about, you know, realizing that you do have power as a student."

Students also saw the IBL-HE classroom as involving "a deeper student and instructor relationship" for some, "instead of a view of an instructor as an authority figure, they are perceived as a trusted confident." This did not however negate their desire for instructors to maintain professional boundaries. While one student suggested that the boundaries were unspoken as they kidded, "We used to go for beer after class...Yeah! But don't come over to my house", another noted that this mutually negotiated sharing of power impacted their ability to fully engage in IBL-HE:

I saw that they trusted me and my opinions and my values and, you know, didn't just see me as just another student... and I think that that's how I was able to kind of buy into the process a little bit more...you didn't necessarily lose that [professional] relationship but you just, kind of, it was more than simply student/professor.

Instructors certainly saw themselves as setting the stage because, "they [the students] wanted the presence of the facilitator and not to have the dominance of the teacher" and were unanimous in their belief in "having faith in the process, having faith in the students." Student participants agreed that faith in the process is important, "to really get like the core values...I really had to, you know, trust the whole, you have to trust the whole process of it all too." Ultimately, we understood from participants that everyone brings power to the learning environment and within the IBL experience power shifts and mutually negotiated sharing of power emerges, not necessarily in a linear way, but as IBL-HE learning progresses.

\subsection{Emerging Relationship and Community Building}

Once the stage has been explicitly set for collaborative, mutually negotiated power and responsibility in the IBL-HE classroom, the focus of trust between instructor and students expands to encompass trust between the students themselves. As they work on individual projects in an IBL-HE classroom, student collaboration and mutual-support of each others' learning remains key indicators of success.

\subsubsection{Time}

Participants emphasize that time is a critical component of supporting students in relationship building as noted by a faculty participant, "It takes time, so you have to allocate or allow time for that relationship with your students to develop." For some, time meant over many months or even over multiple semesters, while for others, time might refer to multiple and consecutive days such as happens in block week courses,

You have an immersive environment so that when you establish trust and then it builds on itself over the course of 6 to 8 days, you do not have to bring people back every class because the trust kind of carries forward.

The amount of time might also vary depending on the composition of a course. For example, when the class is large, the amount of time instructors can spend with students may decrease, thereby impacting the ways in which students experience the relationship and their ability to risk and trust. For example, one student participant reflects, "When it comes to risk and trust, second thing is time, is time on the instructor's part. Some of them don't have teaching assistants so time for each student is difficult."

Instructors suggested that trust cannot be rushed and requires patience to develop, "you do our best to model it but everyone takes a different amount of time and under different circumstances." Students agreed that the time it takes to trust varies by person and situation as indicated here,

Obviously, you know hearing about other students' experiences and everything are going to be helpful but when you place your trust in IBL learning and in your peers and your professor it's going to come at different times for everyone.

Once the relationships are established however, students agreed that trust could more easily and quickly be established in the next IBL-HE course, "because we all knew each other it was easier to be vulnerable," and indeed knowing your peers made all the difference, "the real trust came and the risk taking came from being in it with my peers."

\subsubsection{Links to Former Students}

Some participants noted that their instructors jump-started the emergence of relationship and community building in an IBL-HE classroom by linking current students to those who had successfully completed the course in the past. For some this involved showing current students past projects or screening video testimonials from past IBL-HE 
students of their own. In addition, some instructors incorporated learning facilitators into their IBL-HE classrooms; typically, former students who had engaged in IBL courses previously and could support current students in their inquiry journey. As one student put it:

...the experiences past students have had with it can really be a great indicator of what's gonna' come...I had facilitators that were as wonderful as $\mathrm{R}$ was and kinda' helped encourage so much discussion and openness... having somebody else who successfully did it made me feel so much more comfortable to be able to go and do it.

This was particularly effective for instructors using IBL in larger classes where getting to know and interact with students in a meaningful way is extremely challenging.

One instructor indicated they "might only be interacting with one or two groups of maybe six to eight students each group...we then had that close relationship with their groups but wouldn't necessarily know much about the rest of the class at all." The facilitators could provide extra support. The presence, virtual or in-person, of these previous students was reassuring to the students that the instructor could indeed be trusted.

\subsubsection{Even Safer Spaces}

Both instructors and students in our study indicated that another key to relationship and community building in the IBLHE classroom was safer spaces and the impact of valuing the whole person. Students and instructors agreed that a safe space is one in which they are not judged. Our decision to use the term safer spaces however is guided by the observation of one of our student participants who noted, particularly for groups traditionally discriminated against based on race, religion, sexual orientation, and gender expression, "I personally don't believe a safe space is achievable. I think safer spaces can be achieved but an ultimate safe space I don't think is achievable."

Peer support for both faculty and students is one way to facilitate a sense of community in IBL. One instructor said, "I think the peer element, the peer teaching really, um, creates a safe environment for students", while a student noted, "the ability to be honest and the ability to trust the honesty of other people in the room" supported a sense of community building. Another student added, "what I like to see is professors encouraging exploration."

Both faculty and students discussed responsibility for safe spaces as shared and mutual. One participant began the conversation in this way, "trust kind of to me equals that relationship and that caring and respectful environment." Another instructor added, "...openness, an ability to engender acceptance for different views and diversity and abilities... a sense that we are all learners, whether you are a faculty member or a student." A faculty participant said they understood themselves to be a trusted confidant as an IBL instructor. Agreement among all faculty members ensued, "...I like the idea of trusted confidant", along with further ideas about how their role is discussed with students, "...part of that would be sort of brainstorming ideas about their instructor and typically things like mentor and guide would come out so it was more that coaching, mentoring, guiding, facilitating role for the instructor." Faculty participants also saw part of their role as promoting the benefits of IBL for students, "having that belief that this approach [IBL-HE] is beneficial."

Students indicated the ways in which IBL promotes community through supportive, collaborative relationships with peers verses competitive relationships that can be present in traditional teaching classrooms meant "we were more willing to be vulnerable with one another and risk being wrong because we weren't competing with one another to be the top of the class because we were being graded on our process not on getting it right." Other students believe community is developed in IBL environments with ground rules and a few practical tips, "trust, vulnerability and Timbits [edible treats]."

The influence and amount of peer support is a critical component of the IBL process as is noted by multiple students, "peers can make or break it", and, "I think if your peers are buying in as much as you are there can be so much opportunity for like really, really great conversation and expansive inquiry," and from another, "I feel like students trust other students opinions more than a professor especially if they don't know that professor already." Yet, not all students experience supportive peers in the IBL process:

I kind of ended up in a group where like nobody was hyped but me, and there were plenty of times when we'd have like our little meeting that you are supposed to have and it would literally just be me in the facilities and I'd be like okay, cool.

Students agreed that their sense of community is enhanced in the IBL environment when peers are engaged in their learning process, "trust in your peers, they're gonna' hold your hand while you're jumping down that scary rabbit hole." They recognize that community building in an IBL-HE environment requires, "mutual agreement to be curious together and to explore together and also to like take risks together."

More specifically, students indicated that they had to learn to get: 
comfortable being around other people that also may have different perspectives but are willing to sort of navigate the issues with you. As you inquire and draw conclusions you have to trust that if you don't have the same conclusions as they do, they still sort of see where you're coming from.

These observations suggest that while a completely safe space may not be achievable for students, there may be a spectrum of safer spaces where community building can happen. Part of this safety is also embodied in the flexibility provided through IBL-HE for students experiencing real life challenges, for example "if a student is triggered by content, we can look into an alternative assignment," because IBL assignments are based on student interests. A further implication of the safer space noted by faculty participants is that IBL provides the permission and tools for students to observe higher education as something more than a degree, "I think the benefit of the technique is totally that you can shift those who are very credential focused towards a more liberal view about education."

The impact of the trust engendered by these safer spaces on relationship and community building between students and with the instructor were tangible. One student proudly stated that "The confidence to say something rose up because this person made you feel that no matter what you said, would be received with such kindness." Students also noticed that the safe spaces provided, "a richness to be gained by having students come together from multiple places to like share in that like kind of discovery process", "instilled a lot of motivation in me...the aspect of um how active I had to be in my learning kind of motivated me", and, "it is a matter of discovering my own curiosity."

\subsubsection{Valuing the Whole Person}

Faculty participants understood this ability to risk and trust as one of the implications of using IBL when they said, "you can be OK to be yourself and make mistakes, and say things that you might be embarrassed about what [discussion] we are having in another kind of space." One faculty participant highlighted and the rest agreed on the importance of, "Taking the time to get to know the whole people that your students are and creating an environment where they can also learn about the whole person that I am." One instructor shared an experience where they observed this level of trust in the safer space of the IBL-HE environment and described a student sitting in vulnerability in this way, "his [a student's] entire face changed and he kind of looked up and said, 'I don't know, I don't know how I would know if that was good information", when the instructor was checking in about the student inquiry process.

Transformational learning can happen when collaboration is the focus, power and responsibility are negotiated and shared, and relationship and community building emerges and flourishes (Damianakis, Barrett, Archer-Kuhn, Samson, Matin \& Ahern, 2019). In our study, instructors engaging in IBL-HE marvel at "watching them actually quickly move into understanding what inquiry-based learning is about and seeing transformational change in them, not just in their trust but in their confidence about what they can do." Most student participants agreed to the transformative properties of IBL-HE saying, "I found it enhanced my learning quality so much because I was able to create these key relationships in my classes that allowed me to learn and open my eyes in so many different perspectives." When trust is mutual, collaboration is emphasized, and community spaces are safer places to explore and present oneself as a whole person, the impact can be felt in the depth of student learning, "I'm comfortable in this space...I really felt like I had the safety of my group around me, I was able to kind of push myself deeper into it and really challenge some of my own preconceived notions."

\subsection{Internalizing \& Applying the IBL-HE Mindset Beyond the immediate Classroom}

This idea of transformation in IBL-HE learning can be seen when students talk about their desire and willingness to engage in IBL-HE type thinking and activity outside the classroom as well. One instructor described an example of students traveling to a tournament who had internalized their professor's sense of trust in them outside the classroom walls. The instructor said "I got an email with a video attached that said, we thought we would share our discussion with you, and there is a bunch of them sitting on the airplane together having talks about their projects." Indeed, the transformative potential of successful IBL-HE can also be in other courses within the university experience. One unexpected consequence of successful IBL-HE is noted by non-IBL instructors, as indicated by this faculty member:

The biggest challenge in the end is being once we put people into IBL and [they are] transformed now, we're having [other] faculty complain that the students are far too disruptive, they ask questions, they're interested in the subject matter, they don't want to just listen to what's being told to them.

This is a good problem to have from the perspective of any IBL-HE instructor. Students themselves recalled the impact of their successful IBL-HE experiences throughout the remainder of their university courses and beyond saying, "I've been fortunate enough to have that [IBL-HE] throughout my degree... because of my experiences with IBL that you know if I were to go back to school and do IBL learning I feel that I would still be willing to kind of commit to it." Another student observed, "It changed my degree for me. Honestly. I didn't want to take other classes that were not as engaging." This transformational experience of IBL-HE can even lead to increased care for the learning of others as detailed by one student: 
I found I would have a responsibility if in my other classes if somebody wasn't comfortable or has never done IBL before that I would kind of feel the need to say like oh well look, we're gonna' be talking about things like this. It's like I try to give them a bit of background of my own experiences...having knowledge of somebody else's experience kind of may help them.

This desire to engage with the learning of others as a result of a successful IBL-HE experience was echoed by another student who indicated:

...everybody's got their own projects but essentially here while you're in charge of your projects, you're also learning about 5,6,7, however many people are in your group, all of those other projects in probably fairly reasonable level of depths and ...maybe you know, setbacks that someone's had. Oh, you know "I ran into this problem so, you know, I'm telling you guys this so you guys can avoid this kind of setback in your own project", so there can be a lot of peer learning.

\section{Discussion}

Both students and faculty in our study support Curzon-Hobson's notion that trust is foundational in the pursuit of higher learning. They also confirm that IBL helps to facilitate a learning process whereby intellectual risk is encouraged and supported and wherein trust is further negotiated and developed. Their ability to freely question into and embrace the freedom to pursue their own potentiality and transform as a learner is the essence of a pedagogy of trust (Curzon-Hobson, 2002). Together, these instructors and students agreed that successful IBL-HE is about facilitation of a process in a space that allows students to feel comfortable in getting uncomfortable. It requires ongoing modelling and reinforcement of a particular mindset of inquiry that can and should transfer to other learning experiences. This does not mean that it will be a smooth road for everyone or that every student will be at the same place in IBL-HE trust cycle at the same time.

A number of themes embedded in our proposed model illustrate a pedagogy of trust including perceptions of instructors (creating environment of negotiated mutuality), and perceptions of power (shared but not equal power). These perceptions were common among students and faculty in our study and provide evidence of the ways in which trust can be developed and maintained utilizing IBL in higher education environments. Safer spaces provide a way to modify the learning environment to create opportunities for a pedagogy of trust to take hold and grow. Getting to trust in higher education requires both students and instructors to step outside of their comfort zone to engage in IBL and become comfortable with the unknown.

It was here where community building happens that we begin to see students showing signs of shifting their perspectives, trusting both peers and faculty. Student participants appeared to go from a perspective of peers as competitors to peers as collaborators where they defined the safer spaces through their acts of vulnerability and valuing the whole person. The perspective transformation (Mezirow, 2012) that is observed allows students to shift their mindset about learning. Using IBL as a pedagogy, students increase collaboration and ownership of their learning.

Taking intellectual risks in the IBL environment means that the student has decided to trust the process or the person (instructor) or both. Trusting one (the process) or the other (the person) our participants shared, can yield positive learning experiences, for example, students can have successful learning experiences in an IBL environment when they trust the process provided the person is not untrustworthy. Trusting the person without necessarily trusting the IBL process can still yield positive learning experiences for students provided they engage in their learning based on their faith of a positive student/faculty relationship.

Instructors and students all identified vulnerability as necessary for trust to develop. This vulnerability goes beyond the student taking intellectual risks and includes instructors modelling vulnerability to set the stage and inspire students to trust. Indeed, students expressed that trust is built when they observe instructors being vulnerable, sharing their experiences, acknowledging when things didn't go well, saying "I don't know" when the answer may not be clear. Instructors said the relational nature of IBL exposes them as human, hanging on a limb even, at times when they leave themselves open to criticism or "getting it wrong". Students appreciate the relational nature of IBL, particularly having instructors show that they care about them as people, beyond their role as student, and when instructors reveal their interest in students' learning journey. Students and instructors value the student/instructor relationship and see it as a necessary component to developing trust, quickly or otherwise, in a course.

Faculty and students agree that in that relationship, power can be shared but is not equal even when using IBL as a teaching and learning strategy. Students appreciate transparency from instructors who openly discuss power relations, instructor and student power, and the shifting nature of power in IBL. Students confirmed that they do not want power to be equal as the imbalance of power in favour of instructors provides a safety net for students when they require help. Instructors acknowledged their awareness of the power imbalance, placed responsibility for acknowledging the power imbalance squarely on themselves, and also discussed their intentionality at mitigating power relations. Instructors believe their 
willingness to be vulnerable in the class is an important way in which they can mitigate power when reducing the notion of the all-knowing expert. Perceiving themselves as learners is another way that faculty understand their ability to shift and share power with students in the course, from authority figure to trusted confidant.

Time is one important component of risk and trust in IBL yet often there is little time available to students especially when you consider the unique constellation of circumstances in higher education such as short semesters and large classes. This is an area that requires further investigation as to the "how to" of time.

Students and faculty understand trust to occur within safer spaces and they spoke of the modifications to traditional learning spaces that can facilitate a trust pedagogy while using IBL. These modifications included the role of the relational nature of the instructor as a trusted confidant, mentor, guide, and coach. Creating these safer spaces was identified by faculty as requiring intentional attention throughout the semester suggesting that trust is an ongoing process and can be both fostered and diminished. Indeed, student spoke of having some responsibility for the creation of safer spaces in the ways in which they interact with peers. The learning community includes faculty and students, yet, peer feedback is such a critical component of IBL that it requires peers to engage in their own learning and the learning of their peers by way of intentional support, noted as being curious together.

Students and faculty members observe IBL as risky and involving high stakes. Students want to know they are learning what they need to learn, and all importantly to them, is the final grade. They are used to traditional teaching approaches and have learned to navigate them to attain their required grade, whereas, IBL is unfamiliar, requires more effort, and leaves the student anxious initially about the potential impact on their grade. Faculty members also expressed concern about their own potential consequences utilizing IBL, for example, when a student expresses unhappiness using evaluations of teaching, and ironically also when students praise their experiences of IBL using evaluations of teaching with higher scores than when traditional methods are used. The first example can be problematic for untenured faculty, while the second example can leave administrators questioning the rigor of the teaching and learning strategy. This suggests that not only do faculty need to demonstrate their own trust and belief in IBL and faith in the students, so too is trust required of the instructor by the institution to understand the value of IBL in higher education classroom.

\section{Conclusion}

Our participants, instructors and students alike, discussed and understood trust as a process, something that generally developed over time and with greater experience with IBL-HE. Participants who have experienced intensive short-term courses such as one or two-weeks also suggest that trust can occur more quickly with the essential components noted above of instructor modelling an inquiry mindset and community building through instructor vulnerability and peer collaboration. Overall, both students and faculty members identified a number of ways in which a trusting environment can be created through modifications to traditional learning environments and they understood IBL-HE to facilitate these trusting environments, but not without risks and high stakes, as an empowering and transformational teaching and learning approach. These findings provide evidence for IBL as a pedagogy of trust in higher education, and reinforce the need for Scholarship of Teaching and Learning (SoTL) promoted so strongly in Boyer's Scholarship Reconsidered, and the lifelong learning skills desired by contemporary employers.

\section{References}

Aditomo, A., Goodyear, P., Bliuc, A., \& Ellis, R. A. (2013). Inquiry-based learning in higher education: principal forms, educational objectives and disciplinary variations. Studies in Higher Education, 38(9), 1239-1258. https://doi.org/10.1080/03075079.2011.616584

Almajed, A., Skinner, V., Peterson, R., \& Winning, T. (2016). Collaborative learning: Students' perspectives on how learning happens. The Interdisciplinary Journal of Problem-based Learning, 10(2). https://doi.org/10.7771/15415015.1601

Anstey, L. M. (2017). "Applying anatomy to something I care about”: Authentic inquiry learning and student experiences of an inquiry project. Anatomical Sciences Education, 10(6), 538-548. https://doi.org/10.1002/ase.1690

Anstey, L. M., Michels, A., Szymus, J., Law, W., Edwin, H., Man-Humn, ... Chow, N. (2014). Reflections as near-peer facilitators of an inquiry project for undergraduate anatomy: Successes and challenges from a term of trial-and-error. Anatomical Sciences Education, 7(1), 64-70. https://doi.org/10.1002/ase.1383

Archer-Kuhn, B., Chalifoux, J., \& Wiedeman, D. (2020). Student engagement and deep learning in social work education: Reflections on inquiry-based learning on our group study program course in the UK. Journal of Higher Education Outreach and Engagement (in press).

Archer-Kuhn, B., Lee, Y., Finnessey, S., \& Liu, J. (2020). Inquiry-based learning as a facilitator to student engagement in higher education. Teaching and Learning Inquiry, 8(1). https://doi.org/10.20343/teachlearninqu.8.1.13 
Armstrong, D., Gosling, A., Weinman, J. \& Marteau, T. (1997). The place of inter-rater reliability in qualitative research: an empirical study. Sociology, 31, 597-606. https://doi.org/10.1177/0038038597031003015

Beiter, R., Nash, R., McCrady, M., Rhoades, D., Linscomb, M., Clarahan, M., \& Sammut, S. (2015). The prevalence and correlates of depression, anxiety, and stress in a sample of college students. Journal of affective disorders, 173, 9096. https://doi.org/10.1016/j.jad.2014.10.054

Beltrano, N., Archer-Kuhn, B., \& MacKinnon, S. (under review). A Rapid Systematic Review and Research Synthesis on Trust and Early Engagement in Post-Secondary Inquiry-Based Learning Environments. Canadian Journal for the Scholarship of Teaching and Learning (under review)

Blumer, H. (1969). Symbolic Interactionism: Perspective and method. Englewood Cliffs, NJ: Prentice-Hall.

Bolhuis, S. M. (2003). Towards process-oriented teaching for self-directed lifelong learning: A multidimensional perspective. Learning and Instruction, 13(3), 327-347. https://doi.org/10.1016/S0959-4752(02)00008-7

Boyle, S. L., \& MacKinnon, S. L. (2016). Speed Bumps or Road Blocks? Students' Perceptions of Barriers to Learning \& Developing Academic Resilience. Proceedings of the Association of Atlantic Universities' 2016 Teaching Showcase.

Braye, S., Lebacq, M., Mann, F., \& Midwinter, E. (2003). Learning social work law: An enquiry-based approach to developing knowledge and skills. Social Work Education, 22(5), 479-492. https://doi.org/10.1080/0261547032000126425

Brubaker, N. D. (2012). Negotiating authority through cultivating a classroom of inquiry. Teaching and Teacher Education, 28, 240-250. https://doi.org/10.1016/j.tate.2011.10.002

Bunce, L., Baird, A., \& Jones, S. E. (2017). The student-as-consumer approach in higher education and its effects on academic performance. Studies in Higher Education, 42(11), 1958-1978. https://doi.org/10.1080/03075079.2015.1127908

Charmaz, K. (2006). Constructing Grounded Theory. A Practical Guide Through Qualitative Analysis. Thousand Oaks, CA: Sage.

Charmaz, K. (2014). Constructing Grounded Theory. Thousand Oaks, CA: Sage.

Cook, S. A., \& Borkovitz, D. K. (2017). Student perception of a mathematics major for prospective elementary teachers with an inquiry-based philosophy. Problems, Resources, and Issues in Mathematics Undergraduate Students, 27(1), 125-147. https://doi.org/10.1080/10511970.2016.1194341

Cooper, T., Bailey, B., Briggs, K., \& Holliday, J. (2017). Assessing student openness to inquiry-based learning in precalculus. Problems, Resources, and Issues in Mathematics Undergraduate Studies, 27(7), 736-753. https://doi.org/10.1080/10511970.2016.1183155

Coplin, B. (2012). 10 Things Employers Want You to Learn in College, Revised: The Skills You Need to Succeed. Random House Digital, Inc.

Creswell, J. (2013). Qualitative inquiry \& research design: Choosing among five approaches (3rd ed.). Washington, DC: Sage.

Crick, R. D. (2009). Inquiry-based learning: Reconciling the personal with the public in a democratic and archaeological pedagogy. The Curriculum Journal, 20(1), 73-92. https://doi.org/10.1080/09585170902764021

Cuneo, C., Harnish, D., Roy, D., \& Vajoczki, S. (2012). Lessons learned: The McMaster inquiry story from innovation to institutionalization. New Directions for Teaching and Learning, 129, 93-104. https://doi.org/10.1002/tl.20010

Damianakis, T., Barrett, B., Archer-Kuhn, B., Samson, P., Matin, S., \& Ahern, C. (2019). Teaching for transformation: Masters of social work students identify teaching approaches that made a difference. Journal of Transformative Education. https://doi.org/10.1177/1541344619865948

Dyche, L., \& Epstein, R. M. (2011). Curiosity and medical education. Medical Education, 45(7), 663-668. https://doi.org/10.1111/j.1365-2923.2011.03944.x

Friesen, S., \& Scott, D. (2013). Inquiry-based learning literature review. Available at: https://inspiring.education.alberta.ca/wp-content/uploads/2014/04/Inquiry-Based-Learning-A-Review-of-theResearch-Literature.pdf

Gopnik, A., Meltzoff, A. N., \& Kuhl, P. K. (1999). The scientist in the crib: Minds, brains, and how children learn. William Morrow \& Co. 
Hairida, H. (2016). The effectiveness using inquiry based natural science module with authentic assessment to improve the critical thinking and inquiry skills of junior high school students. Journal Pendidikan IPA Indonesia, 5(2), 209215.

Harvie, L., Harper-Travers, S., \& Jaeger, A. (2017). Assessment within ILP: A journey of collaborative inquiry. Journal of Educational Leadership, Policy and Practice, 32(1), 133.

Henschke, J. A. (2013). Trust in learning-Makes all the difference. In Boden-McGill, C.\& King, K P. (Eds.), Conversations About Adult Learning in Our Complex World, 15-31.

Hudspith, B., \& Jenkins, H. (2007). Teaching the Art of Inquiry. Green Guide No 3. Society for Teaching and Learning in Higher Education. University of Western Ontario. London, Ontario Hudspith, B., Jenkins, H., \& Hills, S. (2003). Teaching the art of inquiry. The Canadian Journal of Higher Education, 33(3), 123.

Inglis-Jassiem, G., Statham, S. B., \& Hanekom, S. D. (2014). What does an enquiry-based approach offer undergraduate physiotherapy students in their final year of study? African Journal of Health Professions Education, 6(2), 192-197. https://doi.org/10.7196/AJHPE.532

Justice, C., Rice, J., Roy, D., Hudspith, B., \& Jenkins, H. (2009). Inquiry-based learning in higher education: administrators' perspectives on integrating inquiry pedagogy into the curriculum. Higher education, 58(6), 841. https://doi.org/10.1007/s10734-009-9228-7

Litmanen, T., Lonka, K., Inkenen, M., Lipponen, L., \& Hakkarainen, K. (2010). Capturing teacher students' emotional experiences in context: Does inquiry-based learning make a difference? Instructional Science, 40(6), 1083-1101. https://doi.org/10.1007/s11251-011-9203-4

Love, B., Hodge, A., Corritore, C., \& Ernst, D. C. (2015). Inquiry-based learning and the flipped classroom model. Problems, Resources, and Issues in Mathematics Undergraduate Studies, 25(8), 745-762. https://doi.org/10.1080/10511970.2015.1046005

Macfarlane, B. (2009). A leap of faith: The role of trust in higher education teaching. Nagoya Higher Education Research, (9), 221-237.

MacKinnon, S. L. (2017). "The Curiosity Project": Re-igniting the desire to inquire through intrinsically motivated learning and mentorship. Journal of Transformative Learning, 4(1), 4-21.

Maroney, S. A., Finson, K. D., Beaver, J. B., \& Jensen, M. M. (2003). Preparing for successful inquiry in inclusive science classrooms. Teaching exceptional children, 36(1), 18-25. https://doi.org/10.1177/004005990303600102

Marshall, C., \& Rossman, G. (2016). Redesigning qualitative research (5th ed.). Washington, DC: Sage.

McAlister, A., Lee, D., Ehlert, K., Kajfez, R., Faber, C., \& Kennedy, M. (2017). Qualitative coding: An approach to assess inter-rater reliability. In ASEE Annual Conference \& Exposition, Columbus, Ohio. https://peer.asee.org/28777

Rancourt, D. E., \& Archer-Kuhn, B. (2019). Fix science grad students' training gap and create job market-ready graduates. The Conversation, https://theconversation.com/how-universities-can-really-help-phd-grads-get-jobs-118241

Richmond, A. S., Fleck, B., Heath, T., Broussard, K. A., \& Skarda, B. (2015). Can inquiry-based instruction promote higher-level learning? Scholarship of Teaching and Learning in Psychology, 1(3), 208. https://doi.org/10.1037/st10000032

Risley, L. M., \& Petroff, K. M. (2014). Examining the element of trust from multiple perspectives in educational environments. Developing and Sustaining Adult Learners, 3-15.

Shin, J. C., \& Jung, J. (2014). Academics job satisfaction and job stress across countries in the changing academic environments. Higher Education, 67(5), 603-620. https://doi.org/10.1007/s10734-013-9668-y

Smallhorn, M., Young, J., Hunter, N., \& da Silva, K. B. (2015). Inquiry-based learning to improve student engagement in a large first year topic. Student Success, 6(2), 65-72. https://doi.org/10.5204/ssj.v6i2.292

Spronken-Smith, R., \& Walker, R. (2010). Can inquiry-based learning strengthen the links between teaching and disciplinary research? Studies in Higher Education, 35(6), 723-740. https://doi.org/10.1080/03075070903315502

Strauss, A., \& Corbin, J. M. (1990). Basics of qualitative research: Grounded theory procedures and techniques. Thousand Oaks, CA: Sage.

Summerlee, A. J. S. (2018). Inquiry-based learning: A socially just approach to higher education. Journal of Human Behavior in the Social Environment, 28(4), 406-418. https://doi.org/10.1080/10911359.2018.1438956

Ural, E. (2016). The effect of guided-inquiry laboratory experiments on science education students' chemistry laboratory 
attitudes, anxiety and achievement. Journal of Education and Training Studies, 4(4), 217-227. https://doi.org/10.11114/jets.v4i4.1395

von Renesse, C., \& Ecke, V. (2017). Teaching inquiry with a lens toward curiosity. Problems, Resources, and Issues in Mathematics Undergraduate Studies, 27(1), 148-164. https://doi.org/10.1080/10511970.2016.1176973

Wall, K. P., Dillon, R., \& Knowles, M. K. (2015). Fluorescence Quantum Yield Measurements of Fluorescent Proteins: A Laboratory Experiment for a Biochemistry or Molecular Biophysics Laboratory Course. Biochemistry and Molecular Biology Education, 43(1), 52-59. https://doi.org/10.1002/bmb.20837

Wang, P. H., Wu, P. L., Yu, K. W., \& Lin, Y. X. (2015). Influence of implementing inquiry-based instruction on science learning motivation and interest: A perspective of comparison. Procedia-social and behavioral sciences, 174, 12921299. https://doi.org/10.1016/j.sbspro.2015.01.750

Yang, M. (2015). Promoting self-sustained learning in higher education: The ISEE framework. Teaching in Higher Education, 20(6), 601-613. https://doi.org/10.1080/13562517.2015.1052785

Zafra-Gomez, J. L., Roman-Martinez, I., \& Gomez-Miranda, M. E. (2015). Measuring the impact of inquiry-based learning on outcomes and student satisfaction. Assessment \& Evaluation in Higher Education, 40(8), 1050-1069. https://doi.org/10.1080/02602938.2014.963836 


\section{Appendix A}

Table 1. Demographics \& Scaffolding Layout

\begin{tabular}{|c|c|c|c|c|c|}
\hline Type & Length & Role (N) & Gender & Location & Ethnicity \\
\hline \multicolumn{6}{|c|}{ Step One: Educators } \\
\hline Focus Group \#1 & 90 minutes & $\begin{array}{l}\text { Professors }(\mathrm{N}=4) \\
\text { Educational Developer }(\mathrm{N}=1) \\
\text { Educational non-profit program } \\
\text { director }(\mathrm{N}=1)\end{array}$ & $\begin{array}{l}\text { Female } \\
(\mathrm{N}=3) \\
\text { Male }(\mathrm{N}=3)\end{array}$ & $\begin{array}{l}\text { Canada }(\mathrm{N}=5) \\
\text { US }(\mathrm{N}=1)\end{array}$ & $\begin{array}{l}\text { Caucasian } \\
(\mathrm{N}=6)\end{array}$ \\
\hline Focus Group \#2 & 70 minutes & Professors $(\mathrm{N}=4)$ & $\begin{array}{l}\text { Female } \\
(\mathrm{N}=3) \\
\text { Male }(\mathrm{N}=1)\end{array}$ & $\begin{array}{l}\text { Canada }(\mathrm{N}=1) \\
\text { US }(\mathrm{N}=1) \\
\text { New Zealand } \\
(\mathrm{N}=1) \\
\text { Ireland }(\mathrm{N}=1)\end{array}$ & $\begin{array}{l}\text { Caucasian } \\
(\mathrm{N}=4)\end{array}$ \\
\hline \multicolumn{6}{|c|}{ Step Two: Students } \\
\hline Focus Group \#3 & $\begin{array}{l}107 \\
\text { minutes }\end{array}$ & Undergraduates $(\mathrm{N}=4)$ & $\begin{array}{l}\text { Female } \\
(\mathrm{N}=3) \\
\text { Non-binary } \\
(\mathrm{N}=1)\end{array}$ & $\begin{array}{l}\text { Canada }(\mathrm{N}=3) \\
\text { New Zealand } \\
(\mathrm{N}=1)\end{array}$ & $\begin{array}{l}\text { Caucasian } \\
(\mathrm{N}=4)\end{array}$ \\
\hline Focus Group \#4 & 64 minutes & $\begin{array}{l}\text { Graduate students }(\mathrm{N}=3) \\
\text { Undergraduates }(\mathrm{N}=3)\end{array}$ & $\begin{array}{l}\text { Female } \\
(\mathrm{N}=6)\end{array}$ & Canada $(\mathrm{N}=6)$ & $\begin{array}{l}\text { Caucasian } \\
(\mathrm{N}=3) \\
\text { First Nations } \\
(\mathrm{N}=1) \\
\text { Asian }(\mathrm{N}=1) \\
\text { Black }(\mathrm{N}=1)\end{array}$ \\
\hline \multicolumn{6}{|c|}{ Step 3: Educators \& Students } \\
\hline $\begin{array}{l}\text { Individual } \\
\text { Interviews }\end{array}$ & $\begin{array}{l}26-75 \\
\text { minutes }\end{array}$ & Professors $(\mathrm{N}=5)$ & $\begin{array}{l}\text { Female } \\
(\mathrm{N}=3) \\
\text { Male }(\mathrm{N}=2)\end{array}$ & $\begin{array}{l}\text { Canada }(\mathrm{N}=4) \\
\text { US }(\mathrm{N}=1)\end{array}$ & $\begin{array}{l}\text { Caucasian } \\
(\mathrm{N}=5)\end{array}$ \\
\hline $\begin{array}{l}\text { Individual } \\
\text { Interviews }\end{array}$ & $\begin{array}{l}17-82 \\
\text { minutes }\end{array}$ & $\begin{array}{l}\text { Graduate Students }(\mathrm{N}=2) \\
\text { Undergraduates }(\mathrm{N}=2)\end{array}$ & $\begin{array}{l}\text { Female } \\
(\mathrm{N}=4)\end{array}$ & Canada $(\mathrm{N}=4)$ & $\begin{array}{l}\text { Caucasian } \\
(\mathrm{N}=2) \\
\text { Black }(\mathrm{N}=1) \\
\text { First Nations } \\
(\mathrm{N}=1)\end{array}$ \\
\hline
\end{tabular}

\section{Copyrights}

Copyright for this article is retained by the author(s), with first publication rights granted to the journal.

This is an open-access article distributed under the terms and conditions of the Creative Commons Attribution license which permits unrestricted use, distribution, and reproduction in any medium, provided the original work is properly cited. 